\title{
Geochemical and isotopic signatures for the identification of seawater intrusion in an alluvial aquifer
}

\author{
Indu S Nair ${ }^{1}$, S P Rajaveni ${ }^{1}, \mathrm{M} \mathrm{Schneider}^{2}$ and L Elango ${ }^{1, *}$ \\ ${ }^{1}$ Department of Geology, Anna University, Chennai 600 025, India. \\ ${ }^{2}$ Institute of Geological Sciences, Freie Universitaet Berlin, Germany. \\ *Corresponding author.e-mail: elango@annauniv.edu
}

Seawater intrusion is one of the alarming processes that reduces the water quality and imperils the supply of freshwater in coastal aquifers. The region, north of the Chennai city, India is one such site affected by seawater intrusion. The objective of this study is to identify the extent of seawater intruded area by major geochemical and isotopic signatures. A total of 102 groundwater samples were collected and analysed for major and minor ions. Groundwater samples with electrical conductivity (EC) greater than $5000 \mu \mathrm{S} / \mathrm{cm}$ and a river mouth sample were analyzed for Oxygen-18 $\left(\delta^{18} \mathrm{O}\right)$ and Deuterium $\left(\delta^{2} \mathrm{H}\right)$ isotopes to study their importance in monitoring seawater intrusion. The molar ratio of geochemical indicators and isotopic signatures suggests an intrusion up to a distance of $13 \mathrm{~km}$ from the sea as on March 2012 and up to $14.7 \mathrm{~km}$ during May 2012.

\section{Introduction}

Seawater intrusion is the ingress of seawater into confined or unconfined coastal aquifers, which in turn affects the quality of groundwater. As the coastal aquifers are generally connected hydraulically to the sea, the seawater which is slightly denser initially intrudes at the bottom of the aquifer and the fresh water present at the top. Over-exploitation of groundwater from such coastal aquifers to meet the increasing demand, accelerates the progress of seawater further towards the land. This will lead to the abandoning of production wells due to contamination of groundwater owing to the mixing of seawater. Seawater is characterized by the dominance of $\mathrm{Na}$ and $\mathrm{Cl}$ with the total dissolved solids of about $35,000 \mathrm{mg} / \mathrm{l}$. The molar ratio of $\mathrm{Na} / \mathrm{Cl}$ in seawater is 0.86 with an excess of $\mathrm{Cl}$ over the alkali ions $(\mathrm{Na})$, while the molar ratio of $\mathrm{Mg} / \mathrm{Ca}$ in seawater is $4.5-5.2$ with an excess of $\mathrm{Mg}$
(Jones et al. 1999). In contrast, continental fresh groundwater is characterized by a highly variable chemical composition, although the predominant anions are $\mathrm{HCO}_{3}, \mathrm{SO}_{4}$ and $\mathrm{Cl}$ (Fritz et al. 1979; Korfali and Jurdi 2010). The total dissolved solids in fresh groundwater generally vary from 150 to $1500 \mathrm{mg} / \mathrm{l}$. Thus, the mixing trends between seawater and groundwater can be understood from total dissolved solids (>2000 mg/l), Cl (>1000 mg/l) and some minor ions. Mixing can also be identified when electrical conductivity (EC) of groundwater exceeds $3000 \mu \mathrm{S} / \mathrm{cm}$ (Karahanoglu 1997). In seawater intruded regions, the concentration of $\mathrm{Mg}$ will be greater than $\mathrm{SO}_{4}+\mathrm{HCO}_{3}$, and $\mathrm{Cl}$ greater than $\mathrm{Na}$, whereas regions with meteoric waters salinised by the marine salts will have $\mathrm{Na}$ greater than $\mathrm{Cl}$ (Howard and Lloyd 1983). Further, minor ions such as $\mathrm{Br}, \mathrm{F}$ and I are also playing a vital role in the identification of seawater intrusion. Apart from this, the various ionic ratios (e.g., $\mathrm{Cl} / \mathrm{Br}, \mathrm{Na} / \mathrm{Cl}$ )

Keywords. Isotopic signatures; geochemical indicators; seawater intrusion; major ionic ratios; Arani and Koratalaiyar rivers; coastal aquifers; Chennai, India. 
are also used to identify seawater intrusion. In order to study the origin and dynamics of groundwater, the analysis of the variations in the stable isotopes of Oxygen $\left(\delta^{18} \mathrm{O}\right)$ and Hydrogen $\left(\delta^{2} \mathrm{H}\right)$ have been widely used. The distribution of these isotopes in natural waters is used to investigate the source of various water types and possible interconnection between them. The isotopic signatures of each water body differ from place to place and a high contrast in the isotopic signature between groundwater and seawater has been used to confirm the mechanism of seawater intrusion. Stable isotope contents of light elements are generally expressed as isotope ratios. Due to the small differences observed in the isotopic ratios (e.g. ${ }^{2} \mathrm{H} /{ }^{1} \mathrm{H}$ ), the isotope concentrations are expressed as deviations $(\delta)$ between the ratio of the sample and the same ratio in an internationally accepted standard (IAEA 1994). In case of stable isotopes of hydrogen and oxygen in water samples, the reference material is a standard ocean water sample called Vienna-Standard Mean Oceanic Water (VSMOW). Therefore, negative $\delta$ value (lower than the standard) of isotopic ratio represents the isotopically depleted samples whereas positive $\delta$ value represents the isotopically enriched samples. In cases where the contribution of fresh water from the rivers into the sea is dominant, then the isotopic composition of seawater will be lesser than the mean seawater composition (Gonfiantini and Araguás 1988; Vengosh et al. 1999). The water from the coastal aquifers and rivers discharging into the sea have higher isotopic signature than the seawater (Araguás 2003).
Several research studies on seawater intrusion in coastal aquifers were carried out in various parts of the world making use of geochemical indicators (Custodio and Bruggeman 1987; McCaffrey et al. 1987; Gonfiantini and Araguás 1988; Todd 1989; FAO report 1997; Jones et al. 1999; Moujabber et al. 2004, 2006; Appelo and Postma 2005; Slama et al. 2010). Sukhija et al. (1996) used the inorganic water chemistry as a tool to differentiate the current and palaeo-salinities in coastal part of Cauvery basin, India. Desai et al. (1979) studied the sources of salinity and geochemical evolution of seawater in coastal aquifers in part of Gujarat, India. Similarly isotopes of $\delta^{18} \mathrm{O}$ and $\delta^{2} \mathrm{H}$ were used to understand the mixing of seawater with the groundwater by many researchers (Gaye 2001; Araguás 2003; Kim et al. 2003a, b; Faye et al. 2005; Chen and Jiao 2007; Korfali and Jurdi 2010; Nwankwoala and Udom 2011). The coastal aquifers located just north of Chennai, the fourth largest metropolitan city in India is one such site affected by seawater intrusion. About $10 \%$ of city's water requirement is met by pumping groundwater from this area since the year 1969. Earlier studies during 1966-1969 by the Groundwater division of Public Works Department, Government of Tamil Nadu in collaboration with United Nations Development Programme (UNDP) indicate that overpumping of groundwater has led to seawater intrusion extending up to $3 \mathrm{~km}$ (CGWB 2010) and $4 \mathrm{~km}$ in 1970-1975 (Subramanian 1975). An electrical resistivity study conducted by the Chennai MetroWater Supply and Sewage Board (CMWSSB) in collaboration with

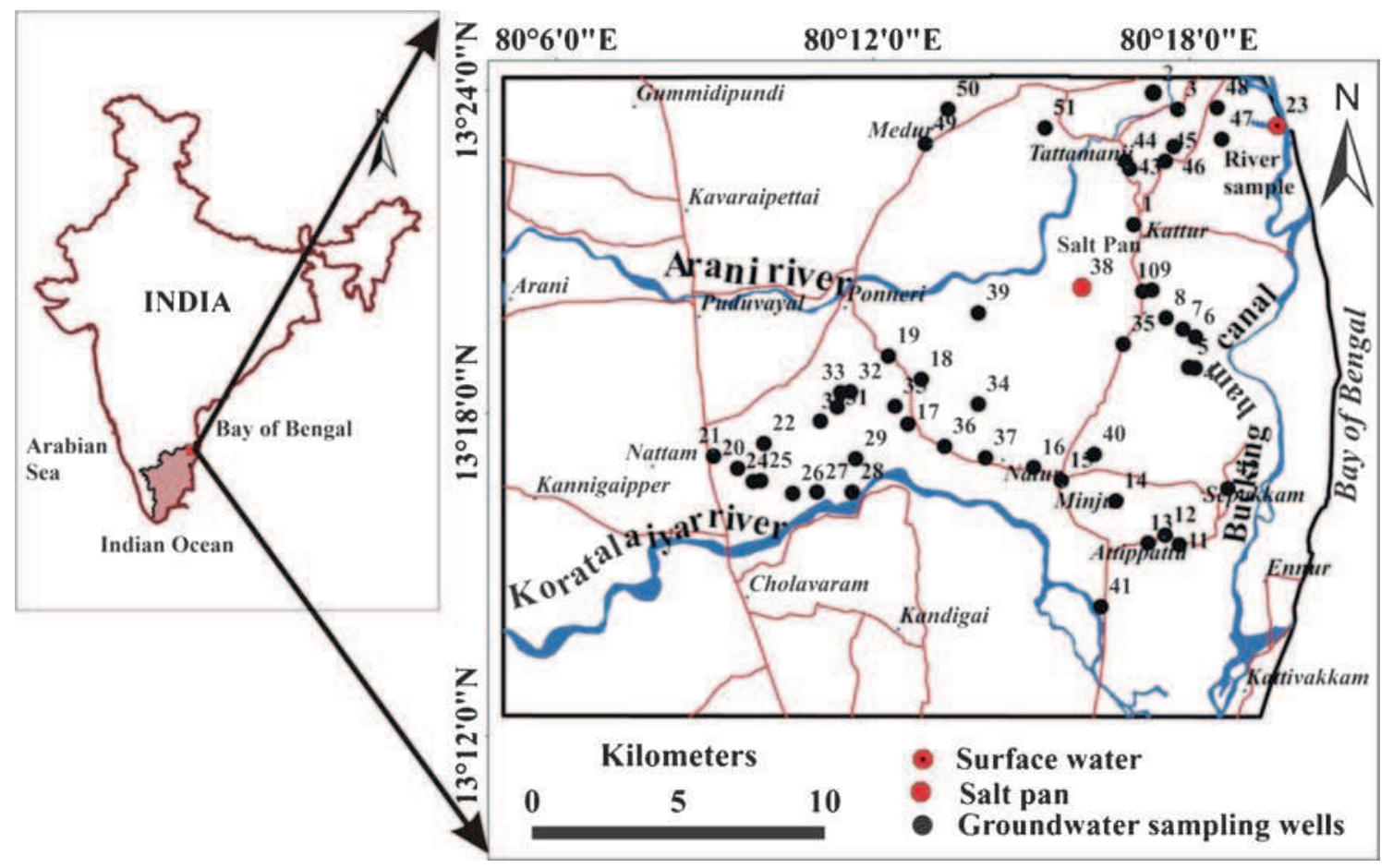

Figure 1. Study area and water sampling locations. 
UNDP during 1983 indicated that the interface was at about $6 \mathrm{~km}$ from the coast. The district groundwater brochure on Thiruvallur district by Central Ground Water Board (CGWB 2007) reported that the seawater has intruded up to $13 \mathrm{~km}$ in the year 2007. A study carried out in 2011 based on $\mathrm{Cl} / \mathrm{Br}$ ratio of groundwater in shallow wells indicated that even the shollow groundwater $(<15 \mathrm{~m})$ has been affected by seawater intrusion up to $8 \mathrm{~km}$ (Indu et al. 2013). Thus, the aquifers located north of Chennai are affected by seawater intrusion since middle of 1960s. Seawater intrusion has affected the landuse and livelihood in the coastal part. It is essential to understand seawater-fresh water dynamics in this area in order to plan for proper mitigation measures. Hence, this study was carried out with the objective of identifying the extent of seawater intrusion by the spatial and temporal variations of geochemical indicators as well as stable isotopic signatures.
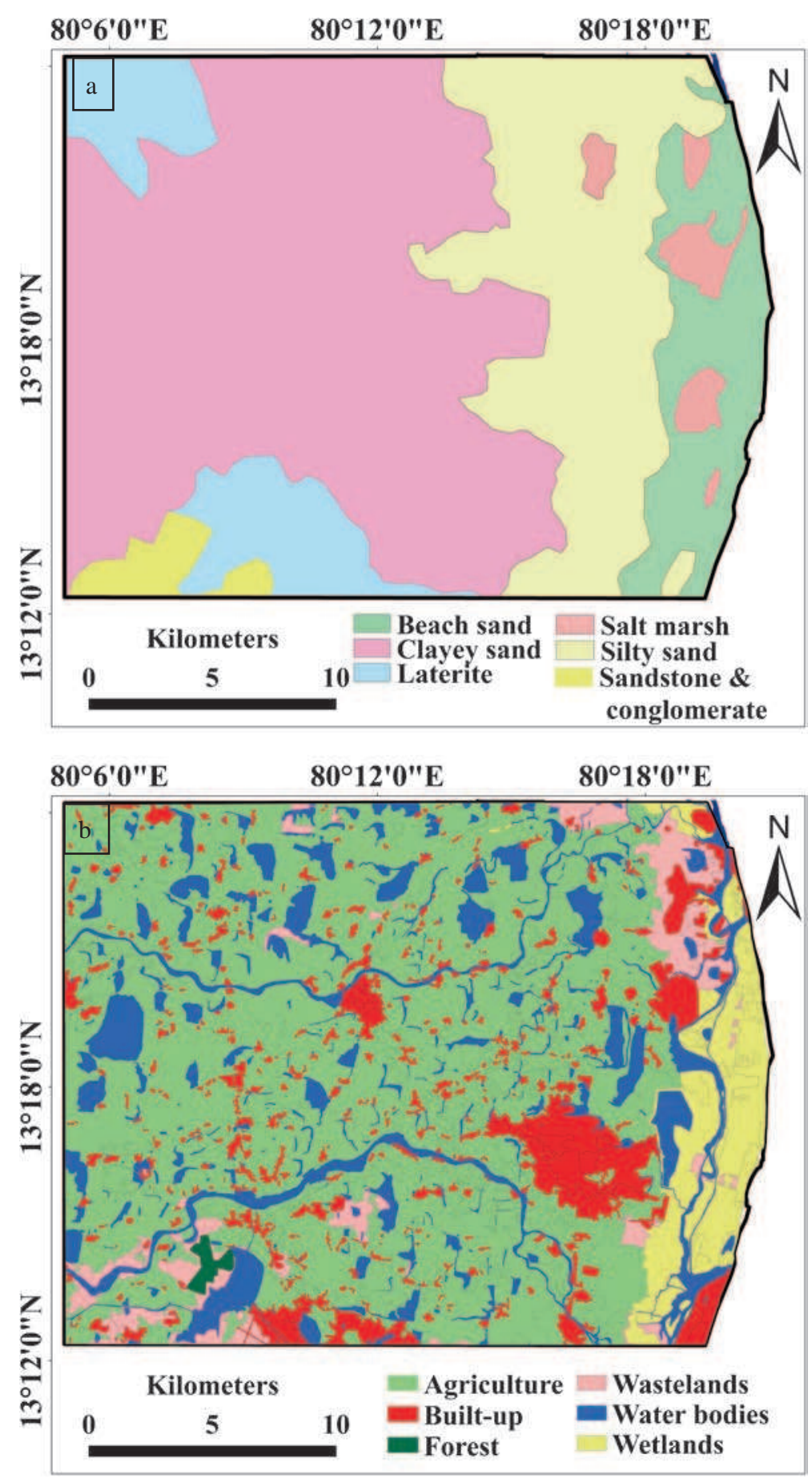

Figure 2. (a) Geology and (b) landuse/landcover pattern. 


\section{Description of the study area}

The study was carried out in a part of AraniKoratalaiyar river basin located north of Chennai, Tamil Nadu (figure 1). The Arani river is located on the northern part of the area, while the Koratalaiyar river is in the south. These two rivers are nonperennial and normally flow only for a few days during northeast monsoon period. The annual average rainfall is about $1200 \mathrm{~mm}$, most of it falling during the northeast monsoon (October-December). The eastern side of the area is bounded by Bay of Bengal and Buckingham Canal which runs parallel to the coast near the eastern boundary of the area and also carries saline backwater. After the monsoon, the river becomes dry and the saline water from the sea enter the river and these backwaters extend inland up to $4 \mathrm{~km}$ (Elango and Manickam 1987; UNDP 1987). Topographically the region gently slopes towards the east apart from some minor depressions with the maximum elevation of about $10 \mathrm{~m}$ along the western boundary. This area predominantly consists of fluvial deposits which include clay, silt, sand, gravel and pebble layers (figure 2a). The underlying clay layers divide the deposit as two layers, with the top layer function as an unconfined aquifer and the bottom layer as a semi-confined aquifer. Charnockites of Archaean age is at the base which is overlain by marine sediments, sand, marine clay and gravel formations followed by clays and silt. About $75 \%$ of the area is covered with marine sediments of tertiary age (Elango and Manickam 1986; UNDP 1987). The drainage in the study area follows dendritic pattern and comprises both fresh water storage lakes and surface water lakes which have been used for domestic purposes. Most of the area is intensively cultivated with rice crops with farms of sizes $2-3$ acres. The main cropping season is from September to January. The eastern part of the area (near the coast) is being used for salt pan activities which are classified as wetlands (figure $2 \mathrm{~b}$ ). The saline groundwater as well as seawater is pumped for the salt pan activity.

\section{Methodology}

Fifty-one well locations were chosen to collect groundwater samples once in two months which cover a distance of $25 \mathrm{~km}$ from the coast and the depth ranges from 4 to $100 \mathrm{~m}$. The samples were collected from both dug wells and borewells of different depths during the months of March and May, 2012. The time periods of March and May were chosen as they represent the peak summer period, when the distance of seawater intrusion is expected to be more due to excessive pumping of groundwater. Groundwater samples were divided based on the well type as shallow groundwater (from dug well $<15 \mathrm{~m}$ ) and deep groundwater (from borewell $>15 \mathrm{~m}$ ). Groundwater was sampled through continuous pumping until the constant values of EC and oxygen reduction potential (ORP) had been established. A water sample from the river was also collected in the month of May 2012. Samples were filtered after retrieval for the analysis of cations and anions using $0.22 \mu \mathrm{m}$ cellulose acetate membrane filters. All samples were stored in airtight bottles. Hydrochemical analyses were performed at Anna University using a high performance Ion Chromatograph (Metrohm 861) which was calibrated with Merk standards. Depending on the EC value, location and depth of the well, water samples from few locations were chosen for stable isotopic analysis. Stable isotopic $\left(\delta^{2} \mathrm{H}, \delta^{18} \mathrm{O}\right)$ analysis was carried out using PICARRO L1102-isotope analyzer at the Museum für Naturkunde in Berlin. For each sample, six repeated injections were performed and arithmetic means and standard deviations were used. Multivariate statistical analysis was also made use to understand the similarities and correlation between the samples. The factor analysis and cluster analysis were performed using Kaiser varimax rotation and Ward's method respectively, in which five parameters including EC, TDS, $\mathrm{Na}, \mathrm{Cl}$ and $\mathrm{Br}$ were considered.

\section{Results and discussion}

A total of 102 groundwater samples and one river water sample were collected during this study. In order to identify the extent of seawater intrusion, indicators such as EC, molar ratio of ions and isotopic contents in both surface water and groundwater were used. The results and inferences arrived are discussed in the following section.

\subsection{Electrical conductivity (EC)}

In coastal areas, groundwater with EC greater than $5000 \mu \mathrm{S} / \mathrm{cm}$ is considered as affected by seawater intrusion (Kim et al. 2003a). The EC of groundwater varied from 400 to $25,000 \mu \mathrm{S} / \mathrm{cm}$ during this study and it increased towards the coast. Very high EC were measured in groundwater of wells closer to the sea in the southern part and few wells from the northern part of the study area. This indicates that the southern part of the area is very much affected by seawater intrusion as well as saline water recharge from salt pans and saline backwaters. 


\subsection{Ionic ratios}

High EC of groundwater is not sufficient to prove the occurrence of seawater as suggested by Revelle (1941). However, the salinity ingress from the sea can be confirmed by analysing the shifts in molar ratios of ions. Many researchers (Kim et al. 2003a, b; Moujabber et al. 2006) have used the ionic ratios to evaluate seawater intrusion in coastal areas in order to identify the source and nature of the salinity present. In the present study, $\mathrm{Cl} / \mathrm{Br}$ and $\mathrm{Na} / \mathrm{Cl}$ were used to delineate region affected by seawater intrusion.

\subsubsection{Cl/Br ratio}

The $\mathrm{Cl} / \mathrm{Br}$ is considered as an authentic tracer of seawater intrusion, as both $\mathrm{Cl}$ and $\mathrm{Br}$ usually behave conservatively, except in the presence of very high amounts of organic matter. Presence of high amount of $\mathrm{Cl}$ and $\mathrm{Br}$ in groundwater is an indicator of the influence of seawater. Several researchers (Morris and Riley 1966; McCaffrey et al. 1987; Richter and Kreitler 1993; Davis et al. 1998; Alcala and Custodio 2008) have used this ratio to identify seawater intrusion. The ratio can also be used to distinguish seawater $(\mathrm{Cl} / \mathrm{Br}=297$, where $\mathrm{Cl}=19,500 \mathrm{mg} / \mathrm{l}, \mathrm{Br}=67.3 \mathrm{mg} / \mathrm{l})$ from remnants of evaporated seawater (hyper saline brine $>297$ ), evaporite-dissolution products $(>1000)$ and anthropogenic sources like sewage effluents (up to 800) or agriculture-return flows (Morris and Riley 1966). The $\mathrm{Cl} / \mathrm{Br}$ of groundwater in the study area varied from 16 to 790 . The ratio exhibits a value $(\geq 297)$ in 21 wells closer to the coast. Values greater than 297 indicate recharge of evaporated seawater from the salt pan as well as backwaters in the rivers and the canal whereas, the values similar to that of the $\mathrm{Cl} / \mathrm{Br}$ ratio of seawater indicates that the groundwater in the coastal aquifer is affected by seawater intrusion. Low $\mathrm{Cl} / \mathrm{Br}$ ratio $(<297)$ in this area may be due to the enrichment of gypsum fertilizer in the soil, which releases inorganic Br to the shallow groundwater as observed by Vengosh et al. (2002). The spatial variation of $\mathrm{Cl} / \mathrm{Br}$ of groundwater for the months of March and May, 2012 are shown in figure $3(\mathrm{a}$ and $\mathrm{b})$ respectively. During March 2012, maximum value of the $\mathrm{Cl} / \mathrm{Br}$ was 790 and the minimum value was 16 and in May 2012, the maximum value was 500 and minimum value was 84 . The extent of the ingress of seawater during March was $12.3 \mathrm{~km}$ from the coast and during May 2012 it was $13.5 \mathrm{~km}$. The wells located on the southern part of the study area had high value of $\mathrm{Cl} / \mathrm{Br}(\geq 300)$ in both March and May 2012, which indicates that the southern part is more affected by seawater intrusion than the northern part. The areal extent of seawater intruded region is higher during May 2012.

\subsection{2 $\mathrm{Na} / \mathrm{Cl}$ ratio}

$\mathrm{The} \mathrm{Na} / \mathrm{Cl}$ in a seawater intruded area would be a mixing product of the ratio in the seawater and the fresh water. The Na/C1 upon mixing between seawater $(\mathrm{Na} / \mathrm{Cl}=0.86)$ and fresh water $(\mathrm{Na} / \mathrm{C} 1>1)$ lies in between 0.86 and 1 (Vengosh and Rosenthal 1994). Low $\mathrm{Na} / \mathrm{Cl}$, combined with other geochemical constituents also indicate seawater intrusion, even at relatively low chloride concentrations, during early stages of salinisation. $\mathrm{Na} / \mathrm{Cl}$ can also be
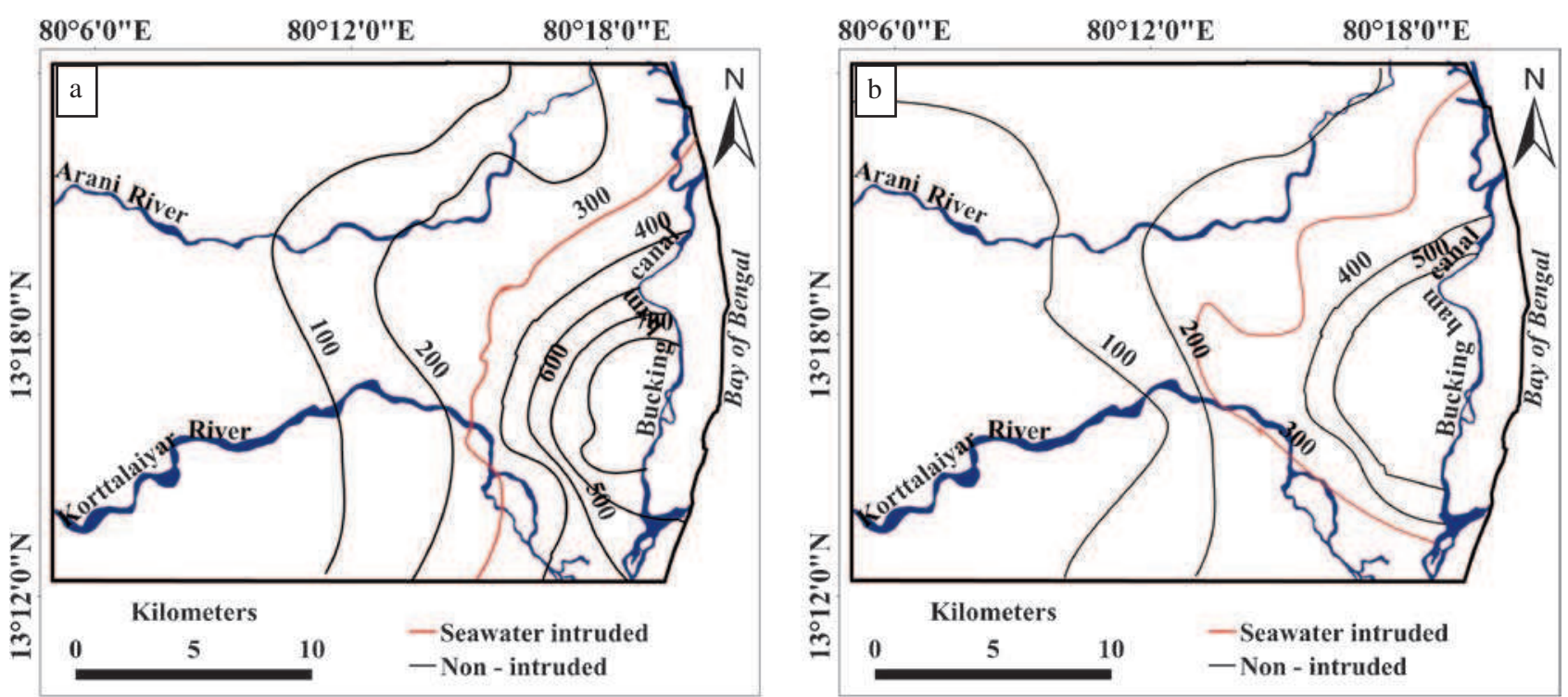

Figure 3. Spatial variations in $\mathrm{Cl} / \mathrm{Br}$ of groundwater in the study area during (a) March 2012 and (b) May 2012, where the value up to 297 ( $\sim 300)$ indicate the region affected by seawater intrusion. 

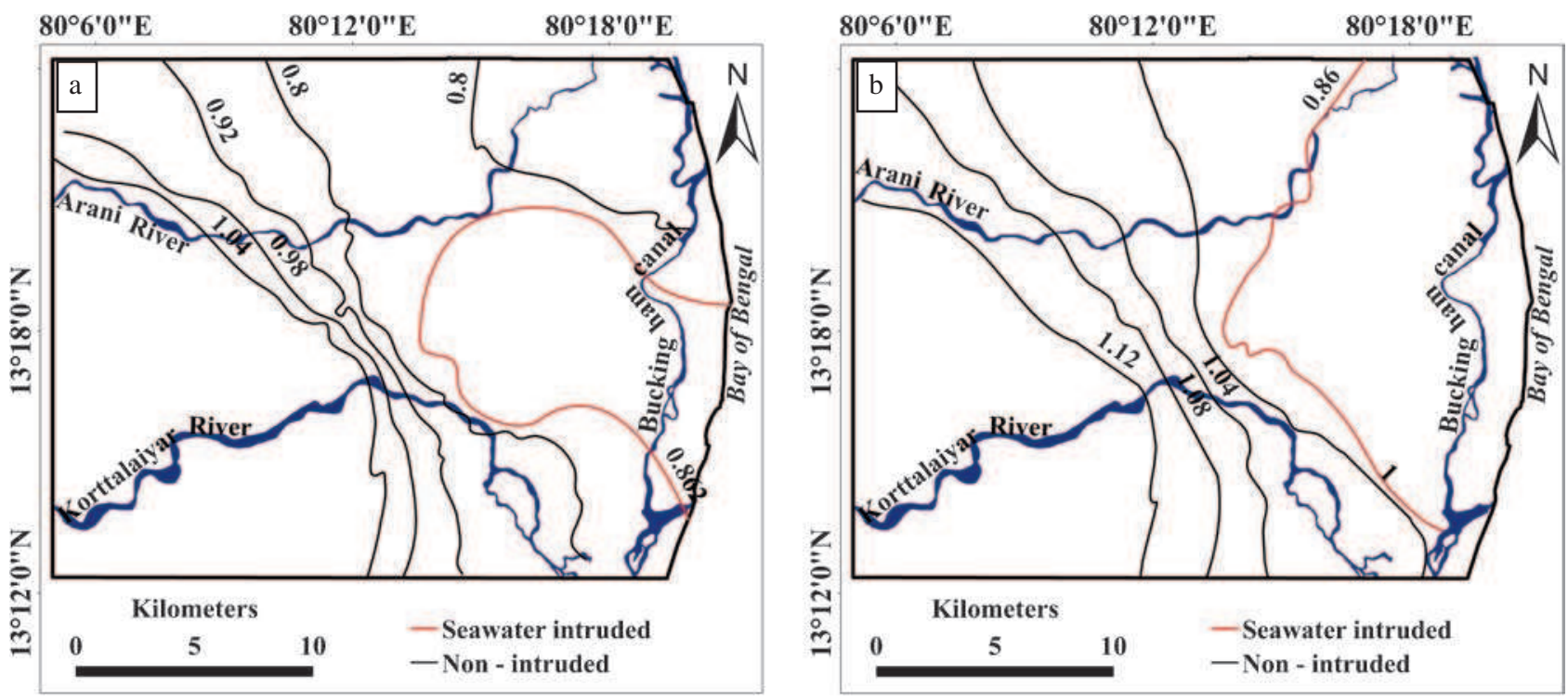

Figure 4. Spatial variations in $\mathrm{Na} / \mathrm{Cl}$ of groundwater in the study area during (a) March 2012 and (b) May 2012, where the value up to 0.86 indicate the region affected by seawater intrusion.

used to differentiate between seawater intrusion and other sources of saltwater and also it has been used to identify the mechanism for saline intrusions (Panteleit et al. 2001; Korfali and Jurdi 2010). They also observed the strong correlation between these two ions in which the concentration of the $\mathrm{Cl}$ remains relatively constant while the ratios begin to drop which suggests the incipient intrusion of seawater. The spatial and temporal variation in $\mathrm{Na} / \mathrm{Cl}$ of groundwater during the months of March and May 2012 is shown in figure 4(a and b) respectively. Since the $\mathrm{Na} / \mathrm{Cl}$ value of seawater is 0.86 , this line is considered as the region up to which the seawater has intruded. The maximum extent of seawater intrusion during March was $14.4 \mathrm{~km}$ from the coast and during May 2012, the maximum extent was $14.7 \mathrm{~km}$. However, the distance of seawater intruded region is comparatively very less in the northern part as indicated by $\mathrm{Cl} / \mathrm{Br}$. The region affected by seawater intrusion in the southern part of the study area is much larger. As in the case of $\mathrm{Cl} / \mathrm{Br}, \mathrm{Na} / \mathrm{Cl}$ also indicates the increase in the areal extent of seawater intrusion during the month of May. This increase in the month of May is due to the overpumping of groundwater on the western part to meet the various needs as it is in the peak of summer period.

\subsection{Isotopic signatures}

In the current study, two sets of groundwater as well as surface samples have been used to understand the isotopic signatures. The samples were chosen based on the concentration of total dissolved solids. Different studies were carried out in the isotopic characterization of precipitation pattern for India's major geographic regions like northern, southern India and Himalayas (Chidambaram et al. 2009; Kumar et al. 2010). The local meteoric water line (LMWL) for south India given by Kumar et al. (2010) has been used in this study.

$$
\delta^{2} \mathrm{H}=7.82 \times \delta^{18} \mathrm{O}+10.22 .
$$

The evaporation enrichment line (figure $5 \mathrm{a}, \mathrm{b}$ ) is calculated with $\delta^{2} \mathrm{H}=4.9 * \delta^{18} \mathrm{O}-1$. A total of 45 samples were collected during the months of March and May 2012 for the isotopic analysis, which includes one surface water sample (Arani river), one groundwater sample from a well located in the salt pan and 20 groundwater samples. The $\delta^{18} \mathrm{O}$ values of the samples range from -5.54 to $1.1 \%$ o and the $\delta^{2} \mathrm{H}$ ranges from 34.21 to $11.5 \%$. Most samples plot close to the right of the LMWL as shown in figure 5. The samples falling on the LMWL during March and May 2012 follow a similar trend and for the convenience of interpretation, the samples were categorized into three groups. The group I waters are isotopically lighter and most of them fall closer to the LMWL and are derived due to rainfall recharge. The samples which are categorized as group II are from wells with a depth of 8-17 m. These samples are categorized as mixed water, i.e., mixture of rainfall derived groundwater and seawater. Group III waters are from wells located closer to the sea which fall between LMWL and evaporation enrichment line. These samples are affected by both seawater intrusion as well as evaporation enrichment of recharging water. One groundwater sample taken from the salt pan indicates positive 

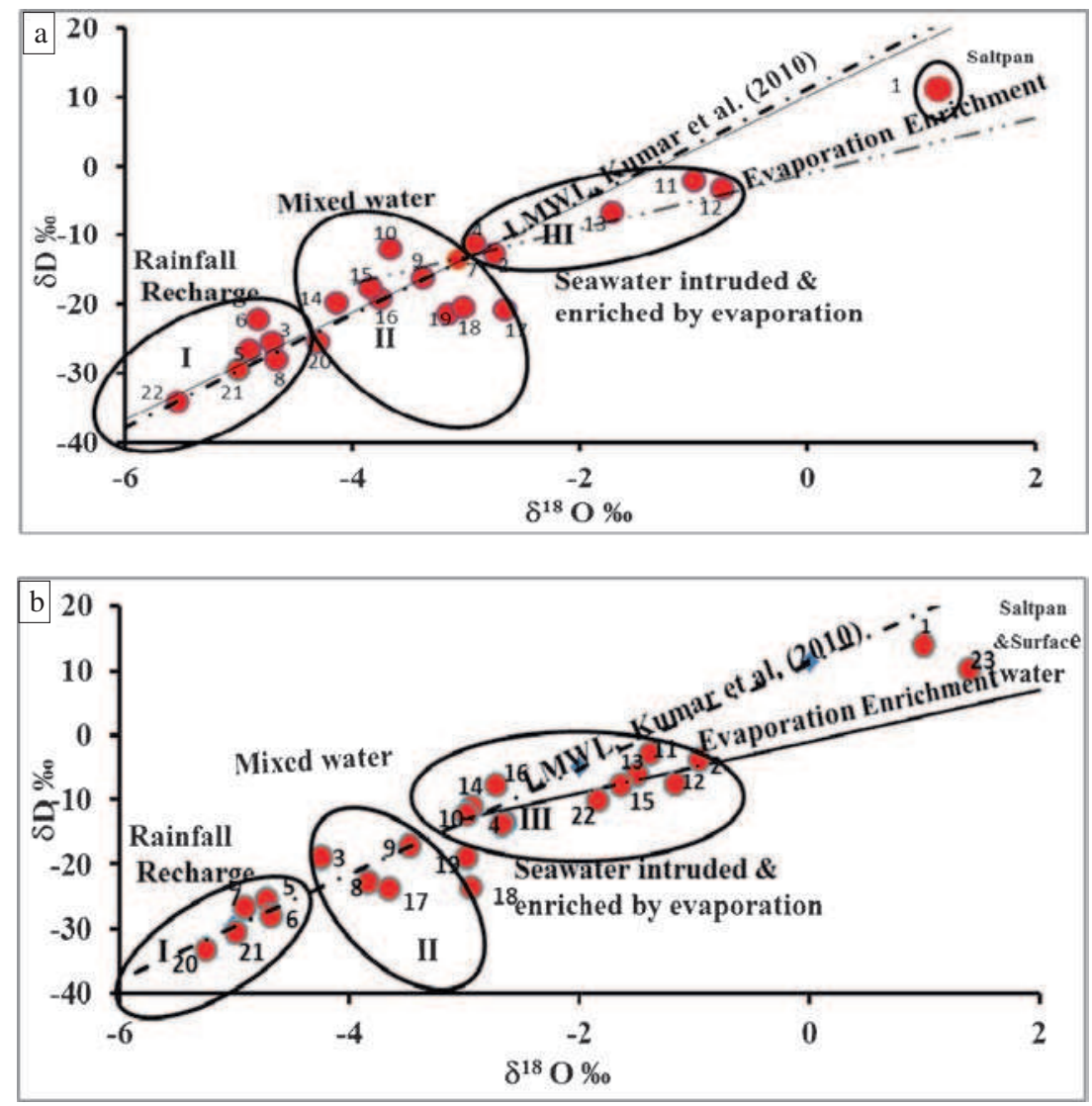

Figure 5. Relation between stable isotopes during (a) March 2012 and (b) May 2012.

enrichment, which indicates the effect of recharge of evaporation enriched water. The surface water sample (No. 23) collected from the mouth of Arani river, plot on the positive side and the recharge of this water will lead to signatures similar to group III waters.

\subsection{Multivariate statistical analysis}

In order to verify the inferences arrived from the geochemical and isotopical signatures discussed, multivariate statistical was used in which all the parameters were considered. The results obtained from the factor and cluster analyses are discussed in this section.

\subsubsection{Factor analysis}

Factor analysis such as principal component analysis (PCA) is one of the techniques employed for the reduction of dimension of variables by correlating their chemical properties as well as their patterns based on covariance matrix. PCA is generally based on the maximum coherence given by diagonal correlation matrix of the data set (Yi et al. 2010). The Kaiser-Mayer-Olkin (KMO) method
Table 1. Factor loading after varimax rotation.

\begin{tabular}{lccccc}
\hline \multirow{2}{*}{ Parameters } & \multicolumn{2}{c}{ March 2012} & & \multicolumn{2}{c}{ May 2012} \\
\cline { 2 - 3 } EC & F1 & F2 & & F1 & F2 \\
TDS & $\mathbf{0 . 9 4}$ & 0.29 & & $\mathbf{0 . 9 8}$ & -0.11 \\
Cl & $\mathbf{0 . 9 4}$ & 0.17 & & $\mathbf{0 . 9 8}$ & -0.11 \\
$\mathrm{Br}$ & $\mathbf{0 . 8 7}$ & 0.33 & & $\mathbf{0 . 9 6}$ & -0.20 \\
$\mathrm{Na}$ & $\mathbf{0 . 7 6}$ & $\mathbf{0 . 3 1}$ & $\mathbf{0 . 9 3}$ & -0.22 \\
O-18 & $\mathbf{0 . 8 8}$ & 0.15 & $\mathbf{0 . 9 0}$ & -0.25 \\
$\mathrm{D}$ & 0.43 & $\mathbf{0 . 5 0}$ & $\mathbf{0 . 6 6}$ & $\mathbf{0 . 5 5}$ \\
Eigenvalue & 4.437 & 1.766 & & 6.160 & 1.000 \\
Variability (\%) & 66.250 & 15.233 & & 76.570 & 7.362 \\
Cumulative (\%) & 66.250 & 79.483 & 76.570 & 83.931 \\
\hline
\end{tabular}

was executed before analyzing PCA and a KMO greater than 0.5 was found suitable for further analysis (Mustapha et al. 2012). The present study obtains a KMO value of 0.673 . The rotated factor loadings, eigen values, percentages of variance and cumulative percentages of variance for both March and May 2012 are given in table 1. The highlighted variables have their absolute values greater than 0.67 showing a strong correlation. The factors with respective eigen values greater than 1.00 are responsible for a higher variation and need 
to be retained (Nura et al. 2013). In the current study, there are two factors for each month which accounts for 79.5 and $84 \%$ of the total variance in the original dataset during March and May 2012 respectively. Factor 1 accounts for the most significant process with a total variance of $66.25 \%$ during March 2012 and 76.57\% during May 2012. The high factor loadings indicate strong correlation among EC, TDS, $\mathrm{Na}, \mathrm{Cl}$ and $\mathrm{Br}$ suggesting the process of seawater intrusion. Factor 2 suggests $15.2 \%$ of total variance during March 2012 with a strong positive loading for isotopic components.

\subsubsection{Cluster analysis}

Cluster analysis (CA) is a statistical tool used for the classification of raw data into various groups or clusters according to their similarities. Shorter the Euclidean distance, higher the similarity between

Table 2. Chemical properties exhibited by each cluster.

\begin{tabular}{llcc}
\hline & & $\begin{array}{c}\text { Seawater-intruded } \\
\text { (cluster 1) }\end{array}$ & $\begin{array}{c}\text { Seawater- } \\
\text { non-intruded } \\
\text { (cluster 2) } N=20\end{array}$ \\
Parameters & Unit & $N=25$ & 2752.208 \\
EC (mean) & $\mu \mathrm{S} / \mathrm{cm}$ & 11971.75 & 1761.413 \\
$\mathrm{TDS}$ (mean) & $\mathrm{mg} / \mathrm{l}$ & 7661.89 & 784.066 \\
$\mathrm{Na}($ mean) & $\mathrm{mg} / \mathrm{l}$ & 1698.78 & 2.531 \\
$\mathrm{Cl}($ mean) & $\mathrm{mg} / \mathrm{l}$ & 2736.545 & 599.201 \\
$\mathrm{Br}$ (mean) & $\mathrm{mg} / \mathrm{l}$ & 9.021 & -4.287 \\
$\mathrm{O} 18$ (mean) & per mil & -1.865 & -24.836 \\
$\mathrm{D}$ (mean) & per mil & -8.952 & \\
\hline
\end{tabular}

the measured objects. In clustering, each group exposes their interaction among the variables or the interrelation among the samples (Yi et al. 2010). A hierarchical dendrogram by Ward's method (figure 6) was made for both March and May 2012 for 45 water samples to identify the groups/clusters followed by $\mathrm{K}$ means clustering method (nonhierarchical). The dendrogram obtained from the analysis shown in figure 6 indicates three clusters. These clusters were reclassified using this method to understand the similarity in hydrochemistry. The output of two major groups has been obtained based on the $\mathrm{K}$ means method which is given in table 2. Cluster 1 (26 samples) has been grouped as samples affected by seawater intrusion. The rest of the sampling locations (19) have been considered as non-intruded samples (cluster 2). The groundwater quality in cluster 2 is better than cluster 1 . The samples from salt pan area during both months and one surface water sample during May 2012 have also been grouped as samples affected by seawater intrusion (cluster 3). Thus, the factor analysis and cluster analysis grouped the wells into seawater intruded and non-intruded wells in accordance with the inference arrived from geochemical and isotopical data.

The seawater intruded area was demarcated based on the geochemical indicators such as $\mathrm{Cl} / \mathrm{Br}$ and $\mathrm{Na} / \mathrm{Cl}$ and isotopic contents. The geochemical analysis confirmed that the seawater intrusion is more in May 2012 than March 2012. Also, it is identified that the seawater intruded up to $13 \mathrm{~km}$ into the land during March 2012 and up to $14.7 \mathrm{~km}$ during May 2012 (figure 7).

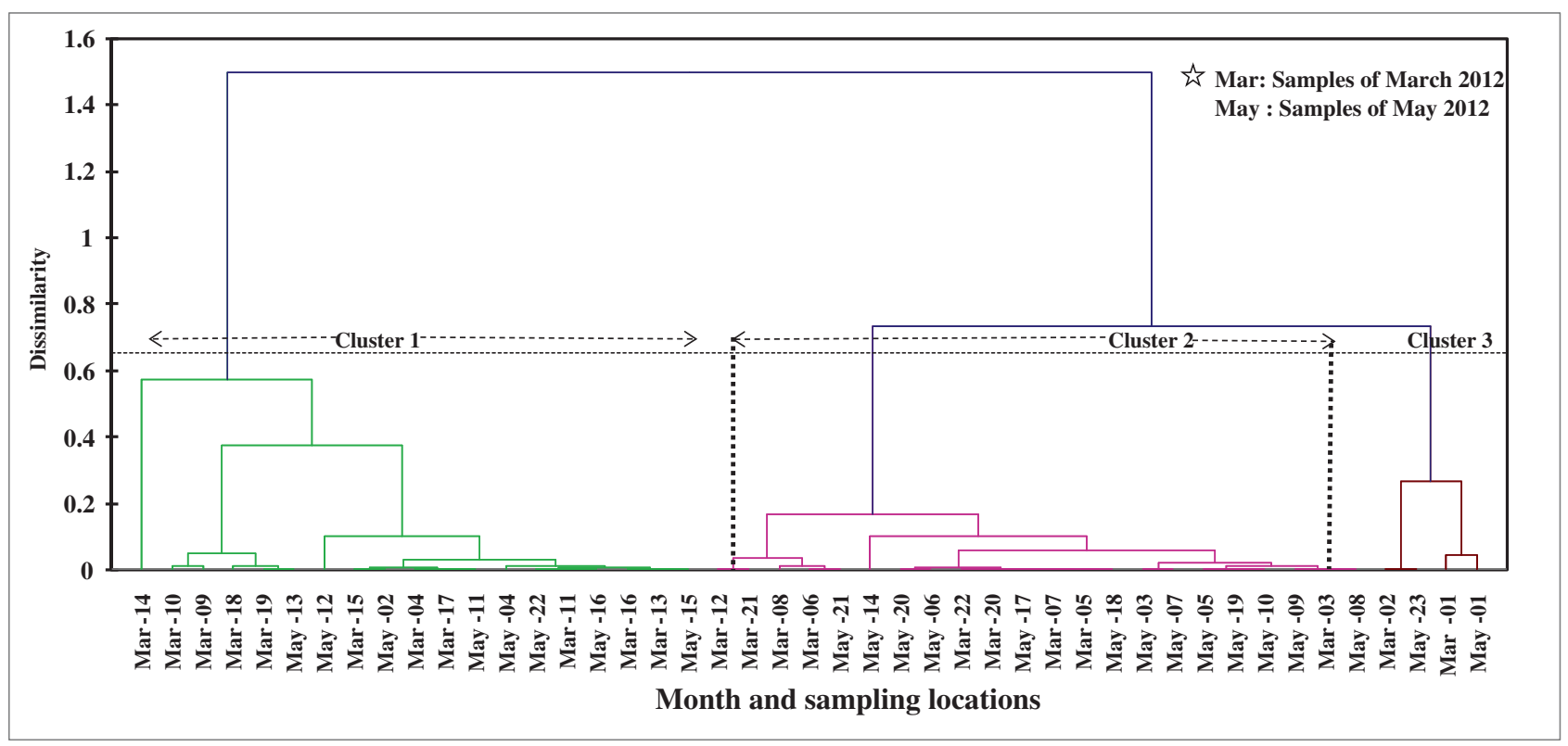

Figure 6. Dendrogram based on the clustering of groundwater data. 


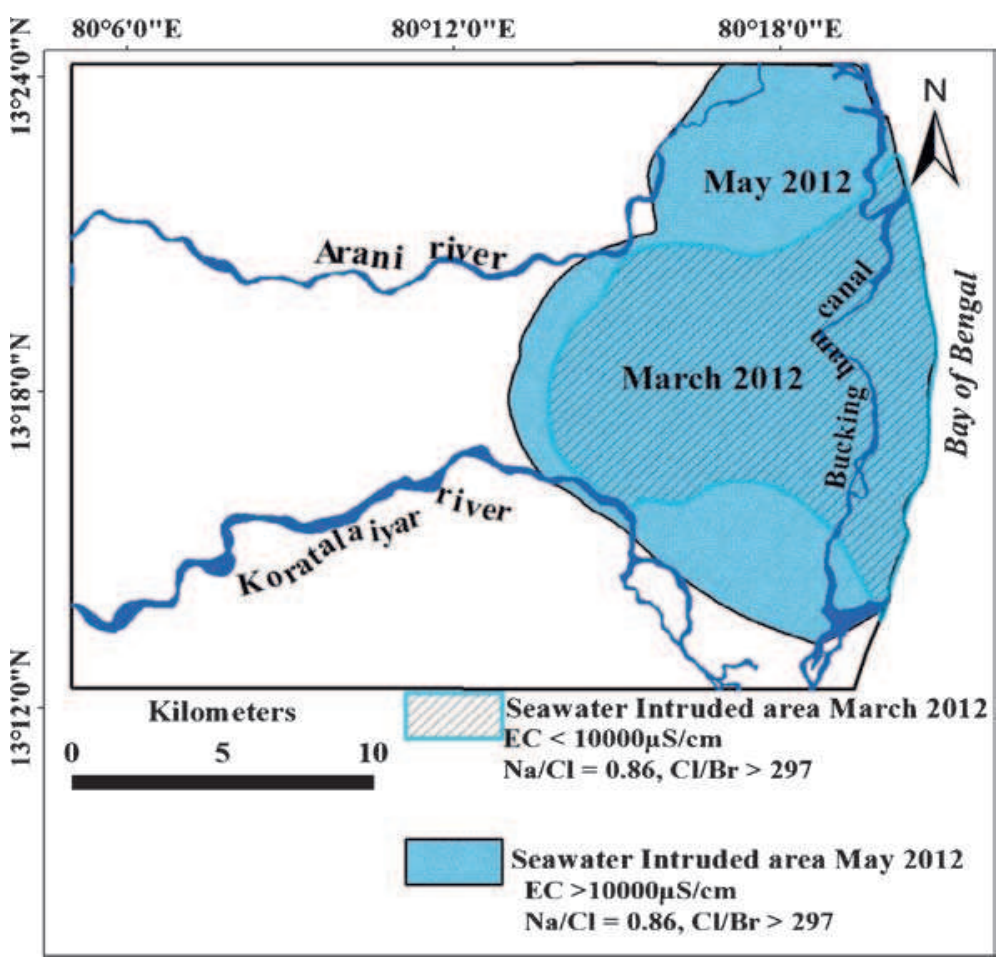

Figure 7. Area affected by seawater intrusion.

\section{Conclusion}

Seawater intrusion is a perennial problem in the aquifers located north of Chennai, and its dynamics was assessed from the geochemical and isotopic signatures of groundwater collected during two different months. The $\mathrm{Cl} / \mathrm{Br}, \mathrm{Na} / \mathrm{Cl}$ and stable isotopic contents were used to delineate the extent of seawater intrusion. The $\mathrm{Cl} / \mathrm{Br}$ and $\mathrm{Na} / \mathrm{Cl}$ of the groundwater ranged from 16 to 790 and from 0.80 to 1.12 respectively. The $\delta^{18} \mathrm{O}$ values of the samples range from -5.54 to $1.1 \%$ and the $\delta^{2} \mathrm{H}$ ranges from 34.21 to $11.5 \%$. Based on these indicators, it is identified that the seawater has intruded up to a distance of $13 \mathrm{~km}$ inland during March 2012 and up to $14.7 \mathrm{~km}$ during May 2012. The factor analysis of the geochemical data supports the process of seawater intrusion and cluster analysis grouped the wells into seawater intruded and non-intruded wells in accordance with the inference arrived from geochemical and isotopical data. The increase in areal extent of seawater intrusion during May indicate the effect of overexploitation of groundwater during the peak summer period. The area affected by seawater intrusion was demarcated based on this study. This will help to plan for initiatives which have to be taken to improve groundwater storage by managed aquifer recharge.

\section{Acknowledgements}

The authors wish to acknowledge the Department of Science and Technology, New Delhi, India for providing fund to this research (Grant no.: DST/ WAR-WSI/05/2010). Co-funding for the collaborative project 'Enhancement of natural water systems and treatment methods for safe and sustainable water supply in India - Saph Pani' (www.saphpani.eu) from the European Commission within the Seventh Framework Programme (grant agreement no. 282 911 ) is also gratefully acknowledged. Stable isotope analysis at the Museum für Naturkunde in Berlin by Dr. Ulrich Struck is greatly acknowledged.

\section{References}

Alcala F J and Custodio E 2008 Using the $\mathrm{Cl} / \mathrm{Br}$ ratio as a tracer to identify the origin of salinity in aquifers in Spain and Portugal; J. Hydrol. 359 189-207.

Appelo C A J and Postma D 2005 Geochemistry, groundwater and pollution; 2nd edn, CRC Press, ISBN-10: 649.

Araguás L J 2003 Identification of the mechanisms and origin of salinisation of groundwater in coastal aquifers by isotope techniques; In: Proceedings of $18^{\text {th }}$ salt water intrusion meeting, IGME, pp. 365-371.

Chen K P and Jiao J J 2007 Seawater intrusion and aquifer freshening near reclaimed coastal area of Shenzhen; Water Science and Technology: Water Supply 7(2) 137-145. 
Chidambaram S, Prasanna M, Ramanathan A L, Vasu K, Shahul H A, Warrier U K, Manivannan R, Srinivasamoorthy K and Ramesh R 2009 Stable isotopic signatures in precipitation of 2006 southwest monsoon of Tamil Nadu; Curr. Sci. 96(9) 1224-1229.

Custodio E and Bruggeman G A 1987 Groundwater problems in coastal areas; Studies and Reports in Hydrology $451-576$.

Davis S N, Whittemore D O and Fabryka-Martin J 1998 Uses of chloride/bromide ratios in studies of potable water; Groundwater 36(2) 338-350.

Desai B I, Gupta S K, Shah M V and Sharma S C 1979 Hydrochemical evidence of sea water intrusion along the Mangrol-Chorwad coast of Saurashtra, Gujarat; Hydrol. Sci. 24(1) 71-82.

Elango L and Manickam S 1986 Groundwater quality of Madras aquifer: A study on Panjetti-Ponneri-Minjur area; Indian Geol. J. 61 41-49.

Elango L and Manickam S 1987 Hydrogeochemistry of the Madras aquifer, India - Spatial and temporal variation in chemical quality of groundwater; Geol. Soc. Hong Kong Bull. 3 525-534.

FAO (Food and Agriculture Organization) 1997 Seawater intrusion in coastal aquifers: Guidelines for study, monitoring and control; FAO Water Reports 11. Rome, Italy: FAO 163.

Faye S, Maloszewski P, Stichler W, Trimborn P, Faye S C and Gaye C B 2005 Groundwater salinisation in the Saloum (Senegal) delta aquifer: Minor elements and isotopic indicators; Sci. Total Environ. 343 243-259.

Fritz P, Hennings C S, Suzolo O and Salati E 1979 Isotope hydrology in northern Chile; Int. J. Isotope Hydrol. 2 525-544.

Gaye C B 2001 Isotope techniques for monitoring groundwater salinisation; Proceeding of First International Conference on Seawater Intrusion and Coastal Aquifers - Modeling, Monitoring and Management, Morocco, pp. 23-25.

Gonfiantini R and Araguás L 1988 Los isótoposambientalesen el estudio de la intrusión marina; In: Tecnologíade la Intrusión Marina en acuíferoscosteros (ed.) Lopez-Camacho Camacho B, IGTE, Almuñecar, Spain, pp. $135-190$.

Howard K W F and Lloyd J W 1983 Major ion characterization of coastal saline groundwaters; Groundwater 21(4) 429-437.

Indu S N, Parimala R S and Elango L 2013 Identification of seawater intrusion by $\mathrm{Cl} / \mathrm{Br}$ ratio and mitigation through managed aquifer recharge in aquifers north of Chennai, India; J. Groundwater Res. 2 155-162.

Isotope hydrology investigations in Latin America 1994 IAEA-TECDOC 835.

Jones B F, Vengosh A, Rosenthal E and Yechieli Y 1999 Geochemical investigation of groundwater quality; In: Seawater intrusion in coastal aquifers - concepts, methods and practices, pp. 51-71.

Karahanoglu N 1997 Assessment of sea-water intrusion in a coastal aquifer by using correlation, principal component, and factor analyses; Water Environ. Res. 69(3) 331341.

Kim J H, Kim R H and Chang H W 2003a Hydrogeochemical characterization of major factors affecting the quality of shallow groundwater in the coastal area at Kimje in South Korea; Environ. Geol. 44 478-489.

Kim Y, Lee K S, Koh D C, Lee D H, Lee S G, Park W B, Koh G W and Woo N C 2003b Hydrogeochemical and isotopic evidence of groundwater salinization in a coastal aquifer: A case study in Jeju volcanic island, Korea; J. Hydrol. $270282-294$.
Korfali F I and Jurdi M 2010 Deterioration of coastal water aquifers: Causes and impacts; European Water 29 3-10.

Kumar B, Rai S P, Kumar U S, Verma S K, Garg P, Kumar S V V, Jaiswal R, Purendra B K, Kumar S R and Pande N G 2010 Isotopic characteristics of Indian precipitation; Water Resour. Res., doi: 10.1029/2009WR008532.

McCaffrey M A, Lazar B and Holland H D 1987 The evaporation path of seawater and the co-precipitation of $\mathrm{Br}^{-}$ and $\mathrm{K}^{+}$with halite; J. Sedim. Petrol. 57 928-937.

Morris A W and Riley J P 1966 The bromide/chlorinity and sulphate/chlorinity ratio in seawater; Deep Sea Res. 13 669-705.

Moujabber E L M, Atallah T, Darwish T and Bou Samra B 2004 Monitoring of groundwater salination by seawater intrusion on the Lebanese Coast; Lebanese Sci. J. 5(2) 21-36.

Moujabber E L M, Bousamra B, Darwish T and Atallah T 2006 Comparison of different indicators for groundwater contamination by seawater intrusion on the Lebanese coast; J. Water Resour. Manag. 20 161-180.

Mustapha A, Aris A Z, Juahir H and Ramli M F 2012 Surface water quality contamination source apportionment and physicochemical characterization at the upper section of the Jakara Basin, Nigeria; Arab J. Geosci., doi: 10.1007/s12517-012-0731-2.

Nura U K, Mohammad F R, Wan N A S, Shaharin I, Ahmad Z A and Adamu M 2013 Evaluation of factors influencing the groundwater chemistry in a small tropical island of Malaysia; Int. J. Environ. Res. Public Health 10(5) 1861-1881.

Nwankwoala H O and Udom G J 2011 Hydrochemical facies and ionic ratios of groundwater in Port Harcourt, Southern Nigeria; Res. J. Chem. Sci. 1(3) 87-101.

Panteleit B, Kessels W, Kantor W and Schulz H D 2001 Geochemical characteristics of salinisation-zones in the coastal aquifer test field (CAT-Field) in NorthGermany; In: Proceedings of 5th International Conference on saltwater intrusion and coastal aquifers - monitoring, modelling, and management, Essaouira, Morocco, pp. 1-11.

Revelle R 1941 Criteria for recognition of seawater in groundwater; Trans. Am. Geophys. Union 22 593-597.

Richter B C and Kreitler C W 1993 Geochemistry of saltwater beneath the Rolling Plains, North-Central Texas; Groundwater 24(6) 735-742.

Slama F, Bouhlila R and Tarhouni J 2010 Hydrochemical processes at the seawater-freshwater interface as indicators of seawater intrusion evolution: Case of Korba coastal plain (Tunisia); Proceedings of $21^{\text {st }}$ saltwater intrusion meeting SWIM-21, Portugal, pp. 11-14.

Subramanian S 1975 Report on the systemic geological mapping of quaternary formations in the coastal plains between Minjur and Madras, Tamil Nadu; Unpublished Report, Geol. Surv. India.

Sukhija B S, Varma V N, Nagabhushanam P and Reddy D V 1996 Differentiation of paleomarine and modern intruded salinities in coastal groundwaters (of Karaikal and Tanjavur, India) based on inorganic chemistry, organic biomarker fingerprints and radiocarbon dating; J. Hydrol. 174 173-201.

Todd D K 1989 Sources of saline intrusion in the 400-foot aquifer, Castroville area, California; Report for Monterey country flood control and water conservation district, Salinas, California, p. 41.

UNDP 1987 Hydrogeological and artificial recharge studies; Madras Technical report, United Nations Department of technical co-operation for development, New York.

Vengosh A, Gill J, Davisson M L and Hudson B 2002 A multi-isotope (B, Sr, O, H and $\mathrm{C})$ and age dating $\left({ }^{3} \mathrm{H}-\right.$ ${ }^{3} \mathrm{He}$ and ${ }^{14} \mathrm{C}$ ) study of groundwater from Salinas valley, 
California: Hydrochemistry, dynamics and contamination processes; Water Resour. Res. 38 9-1-9-7.

Vengosh A and Rosenthal A 1994 Saline groundwater in Israel: Its bearing on the water crisis in the country; J. Hydrol. 156 389-430.

Vengosh A, Spivack A J, Artzi Y and Ayalon A 1999 Geochemical and boron, strontium, and oxygen isotopic constraints on the origin of the salinity in groundwater from the Mediterranean coast of Israel; Water Resour. Res. 35 1877-1894.

Yi C H, Chou P Y, Yu C L, Ping K T and Wen M H 2010 Variation of groundwater quality in seawater intrusion area using cluster and multivariate factor analysis; Sixth International Conference on Natural Computation. 